\title{
Does Earnings Management Amplify The Association Between Corporate Governance And Firm Performance?: Evidence From Korea
}

\author{
Sun-A Kang, Kumoh National Institute of Technology, Korea
}

Yong-Shik Kim, Hansung University, Korea

\begin{abstract}
This paper aims to examine whether earnings management strengthens the causal links between corporate governance and firm performance. It examines the association between corporate governance and real activity-based earnings management and extends it to firm performance. This study involves 1,104 listings on the Korean Stock Exchange and finds that real activity-based earnings management decreases if firms have a well-established governance system, and such earnings management could strengthen the causal link between corporate governance and firm performance as measured by Tobin's Q. Our study results are the first empirical evidences that real activity-based earnings management is effectively controlled by a corporate governance system and that it has links between corporate governance and performance. This provides the importance of corporate governance which could effectively constrain real activity-based earnings management, such that eventually influences the firm's performance. In particular, it provides useful insights into corporate structures in which ownership is highly concentrated. Our findings are of great importance for Korea, in which the predominant business structure for large enterprises is that of the chaebol (equivalent to the Japanese keiretsu), which consists of conglomerates of many smaller companies and in which the structure of corporate governance is that of owner control.
\end{abstract}

Keywords: Corporate Governance; Audit committee; Performance; Real activity-based earnings management

\section{INTRODUCTION}

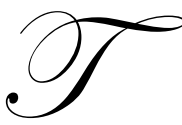

he goal of corporate governance is to ensure the accountability of the manager through mechanisms that try to reduce the principal-agent problem. Whether a corporate governance system effectively works inside is dependent on how it monitors and controls firms and their management with a strong emphasis on shareholders' welfare. The role of corporate governance in financial reporting has received a great deal of attention recently, especially after the passage of the Sarbanes-Oxley Act of 2002 (SOX). Many researchers have examined whether some characteristics of corporate governance effectively constrain managers' earnings management, such that their financial reporting renews public confidence, because SOX requires managers to rigidly enforce the corporate governance system for financial reporting at their own risk. Managers could control reported earnings by making accounting choices or by making operating decisions discretionally. Recent studies show that managers change their method to control reported earnings from accounting choice to real operating decisions, such as postponing a new project or cutting expenses (Graham et al., 2005; Cohen et al., 2008). Earnings management primarily influences firms' performances and eventually may sacrifice the shareholders' wealth. If corporate governance is effective, then managers' discretionary accounting choices and arbitrary operational/investment decisions could both be reduced. It is just as well that enforced corporate governance, after the passage of SOX, reduces managers' accrual-based earnings management. However, if renewed corporate governance doesn't constrain the manager's real operating decisions or investment decisions, then the firm's 
performance will be damaged by the manager's private interests.

This paper examines the role of corporate governance in the context of real activity-based earnings management, first of all, and extends it to firms' performance. If corporate governance influences real activity-based earnings management and strengthens the causal links between corporate governance and firms' performance, it may be that real activity-based earnings management works as a mediator. We focus on board characteristics as corporate governance and consider three kinds of managers' arbitrary business decisions, such as aggressive sales promotions, overproduction, and cutting discretionary expenses. For the test of overall effectiveness, a corporate governance index and combined measure of real activity-based earnings management are used. Both OLS and 2SLS regressions were employed to examine the association between corporate governance and real activity-based earnings management and whether it mediates between corporate governance and firms' performance.

The empirical results show that overall real activity-based earnings management is constrained by overall corporate governance, and the findings are the same when we control for endogenous problems among variables. Finally, we find that strong corporate governance reduces real activity-based earnings management, which results in an increase in firms' performance.

Our finding that real activity-based earnings management can strengthen the association between corporate governance and firms' performance is, to the best of our knowledge, the first empirical evidence of such a relationship. Managers' private interests that could have been pursued via real activities can be constrained by corporate governance in a comprehensive manner, given the relationship that was identified. Further, firms' performance would not be damaged by managers attempting to pursue their private interests if managers' real activity-based earnings management were overseen by corporate governance. The results of the study reported herein suggest that overall board characteristics effectively constrain managers' real activity-based earnings management, which mediates between corporate governance and firms' performance. In particular, the study reveals the importance of controlling managers' arbitrary decisions in a weak governance structure and provides useful insights into corporate structures in which ownership is highly concentrated. Our findings are of great importance for the Korean situation, in which the predominant business structure for large enterprises is that of the chaebol (equivalent to the Japanese keiretsu), which consists of conglomerates of many smaller companies and in which the structure of corporate governance is that of owner control.

\section{REVIEW OF THE LITERATURE AND DEVELOPMENT OF HYPOTHESIS}

\section{Corporate Governance and Firm Performance}

Previous studies examine empirically the relationships between corporate governance and firm value. Most of those studies examine the roles of corporate governance by focusing on factors, such as the composition and/or characteristics of the board of directors or audit committee, and try to determine which factor effectively controls conflicts of interest between owner and manager. However, the results of these studies differ. Some studies support that performance improves as the proportion of external directors on the board increases (Baysinger and Butler, 1985; Dalton et al., 1999; Baek et al., 2004), while other studies find that the proportion of external directors on the board is not related to performance (Hermalin and Weisbach, 1991; Yermack, 1996; Kim, 2006). Those inconsistent results may be caused by an endogenous problem among variables. For example, firm performance may be the result of the efforts of previous directors and at the same time may be an influencing factor on how to choose subsequent directors (Hermalin and Weisbach, 2003).

Previous work on corporate governance structures has also examined such matters as earnings management or management compensation. With respect to earnings management, studies have investigated, as measures of sound accounting practices, whether certain corporate governance structures improve the reliability of accounting reports (Ahmed and Duellman, 2007; Kim and Bae, 2007), the association of corporate governance structures with earnings management using abnormal accruals (Xie et al., 2003; Kim,2006), and the relationship of corporate governance structures with fraud (Beasley,1996; Beasley et al.,2000, 2001; Uzen et al., 2004). In particular, they report that accruals-based earnings management decreases when the proportion of external directors increases, when the size of the board increases, when the number of directors on the board who have a long experience with the 
company increases, and when the number of board meetings increases. Some studies also show that earnings management decreases when the independence of the audit committee increases or the number of meetings of the audit committee increases (Klein, 2002; Xie et al., 2003). These results suggest that as the board becomes more independent from the CEO, it would be more effective in controlling accounting processes. These previous studies all employ accrual-based earnings management, discretionary accruals, as a proxy of earnings management.

\section{Real Activity-based Earnings Management}

In order to meet target earnings, managers make accounting choices among Generally Accepted Accounting Principles (GAAP) and/or make operating decisions that deviate from normal business practices in an attempt to meet target earnings (Roychowdhury, 2006). The former is about managers' accrual-based earnings management and the latter is about real activity-based earnings management. Recent studies report that managers prefer to use real operating decisions, such as postponing a new project or cutting expenses, to manage earnings, rather than to use abnormal accruals (Graham et al., 2005). These preferences seem to have been focused after the SOX Act came into force; that's because accrual-based earnings management is easy to detect from outside, while management arbitrary decisions are more difficult to detect.

Prior studies have been examined on the actual practice of real activity-based earnings management, such as sales of fixed assets or investment to avoid negative earnings growth and violating a debt covenant (Bartov, 1993; Herrmann, Inoue, and Thomas, 2003; Choi, 2004), and recent studies find that firms use multiple real activities to avoid reporting annual losses, such as giving price discounts to temporarily boost sales, overproducing to report a lower cost of goods sold, and reducing discretionary expenditures to improve earnings (Roychowdhury, 2006; Kim et al., 2008). The reason why real activity-based earnings management has gotten much attention recently is because of those economic consequences, which is worse than the case using abnormal accruals. Especially, empirical evidence shows that a manager's abnormal activities have a significantly negative impact on future performance, earnings, and cash flow (Gunny, 2005; Kang and Chun, 2010). These studies identify high abnormal real activity in groups that are using portfolios and find that the manager's discretionary actions negatively influence the firm's performance. They find those negative impacts continue until three years after they are engaged in real activitybased earnings management (Kang and Chun, 2010). This is meaningful because a strict regulation may have a side effect on the firm's long-term performance. There are studies examining the relationship between accruals and real activity-based earnings management (Zang, 2005; Cohen et al., 2008). They report managers use real activity-based methods as a substitute, depending on their strategies. Specifically, firms that are facing a lawsuit or that have filed one tend to switch their earnings management strategies from accrual-based manipulation to a real activity-based one (Cohen et al., 2008). Recent studies also try to identify the incentive for real activity-based earnings management in capital markets, such as outstanding number of shares, external audit quality, or compensation (Cohen et al., 2008), and those characteristics of firms that are engaged in real activity-based earnings management (Kang and Chun, 2010).

\section{Hypothesis Development}

Previous studies report that corporate governance controls managers' accrual-based earnings management and/or may influence firms' performance. However, the effect of corporate governance and the effect of real activity-based earnings management on firms' performance have not yet been investigated. According to Graham et al.'s (2005) survey, firm performance tends to be lower when managers are engaged in real activity-based earnings management. Now we try to link the association between corporate governance and real activity-based earnings management and suggest that real activity-based earnings management mediates between corporate governance and firm performance, as in the causal nexus depicted in Figure 1. 


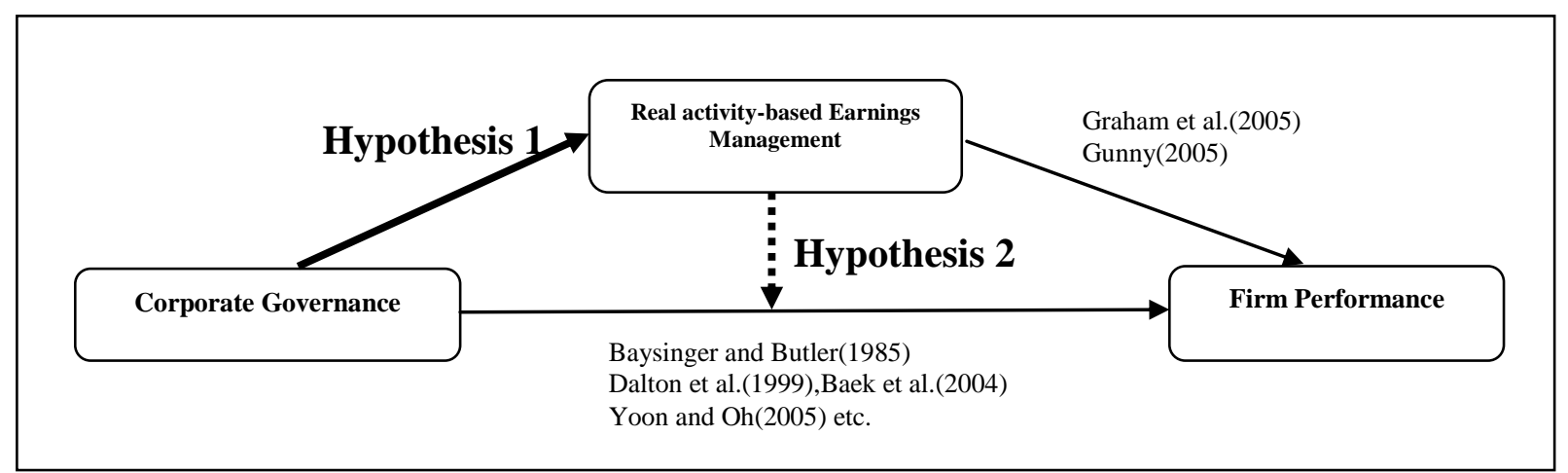

Figure 1: The association among corporate governance, real activity-based earnings management, and firm's performance

Corporate governance and real activity-based earnings management

Board members monitor management and their effectiveness in performing this task depends on the independence, professionalism, and activity of board members (Xie et al., 2003). Introducing a system of external directors ${ }^{1}$ or organizing an audit committee within a firm is a way of decentralizing a board's responsibility and of ensuring that the board discharges its responsibilities properly. Empirical research has shown that both the size of the board and the number of board meetings affect accrual-based earnings management. The possibility of earnings management, whether accrual-based or real activity-based, may have a negative effect on shareholders' accurate access to the true value of the firm and may eventually influence the long-run performance of the firm in response to shocks. Similarly to the case of accrual-based earnings management, boards are charged with monitoring managers to protect shareholders' interests. Managers' abnormal real operational/investment activities are performed in the course of the internal decision process and most of them have to be discussed or approved by the board. That being the case, we expect that the composition of the board will influence whether or not a company engages in earnings management, measured by both abnormal accruals and abnormal real activity. Therefore, real activity-based earnings management could be influenced by board characteristics, such as size, activity, and independence, either directly or indirectly.

\section{Real activity-based earnings management as a mediator between corporate governance and firm performance}

Some studies find that real activity-based earnings management and firm performance are associated negatively (Graham et al., 2005; Zang, 2005). In this situation, if corporate governance controls managers' abnormal real operational/investment decisions effectively, then corporate governance may have a positive influence on firm performance. Several studies report a positive association between corporate governance and performance (Baysinger and Butler, 1985; Dalton et al., 1999; Baek et al., 2004). These findings motivate us to examine whether real activity-based earnings management strengthens the causal link between corporate governance and firm performance. We expect that managers' abnormal real activity amplifies the relationship between corporate governance and firm performance and works as a mediator.

\section{RESEARCH DESIGN}

\section{Model}

In order to examine the role of real activity-based earnings management as a mediator, which amplifies the association between corporate governance and firm performance, we examine whether board characteristics influence real activity-based earnings management using multivariate regressions. Then we analyze whether real activity-based earnings management strengthens the causal link between corporate governance and firm

\footnotetext{
${ }^{1}$ Outside directors are defined as gatekeepers who have a responsibility to prevent corporate misconduct from its management
} and they are not employees of the company. 
performance.

We develop [Model 1] to examine these associations between the characteristics of corporate governance and real activity-based earnings management after controlling for size, leverage, performance, ownership, and compensation.

[Model 1]

$R M_{-}$Proxy $_{i t}=\boldsymbol{\alpha}_{0}+\boldsymbol{\alpha}_{1}$ CORP_INDEX $\boldsymbol{X}_{i t}+\boldsymbol{\alpha}_{2}$ SIZE $_{i t}+\boldsymbol{\alpha}_{3} L_{E V E R A G E}+\boldsymbol{\alpha}_{4} R O A_{i t}+\boldsymbol{\alpha}_{5} O_{\text {OWNER }}+\boldsymbol{\alpha}_{6}$ COMPEN $_{i t}$ $+\boldsymbol{\alpha}_{7} O W N E R \_D U M M Y_{i t}+\boldsymbol{\alpha}_{8 \sim 15} \Sigma I N D \_D u m m y+\boldsymbol{\alpha}_{16 \sim 17} \Sigma Y E A R \_D u m m y+e_{i t}$

where,

RM_proxy $y_{i t}$ : The sum of $A b . O C F, A b . P R O D \_c o s t$, and $A b . E X P$ of firm $i$ in year $t$ (we multiply Ab.OCF and $A b . E X P$ by -1 so that the sum of the three variables will be indicative of overall real earnings management)

CORP_INDEX $X_{i t}$ : The sum of $B \_S C A L E, B \_M E E T$, and $O U T S I D E$ of firm $i$ in year $t$ (we multiply $B \_M E E T$ by -1 so that the sum of the three variables will be indicative of overall corporate governance)

$S I Z E_{i t}$ : Natural $\log$ of total assets of firm $i$ in year $t$

LEVERAGE $i t$ : Debt ratio of firm $i$ in year $t$ (Total Debt $_{i t} /$ Total Assets $_{i t-1}$ )

$R O A_{i t}$ : Return of assets of firm $i$ in year $t$ (Earnings before tax ${ }_{i l} /$ Total Assets ${ }_{i t-1}$ )

$O W N E R_{i t}$ : Large shareholder's ownership of firm $i$ in year $t$

COMPEN $_{i t}$ : Board of directors' compensation of firm $i$ in year $t$

$O W N E R \_D U M M Y_{i t}$ : Indicator variable with a value of 1 if a manager of firm $i$ in year $t$ is an owner, 0 otherwise

IND_Dummy: Industry dummy variables

YEAR_Dummy: Year dummy variables

We consider board size, activities, independence, external directors' activities, and external directors' professionalism as characteristics of corporate governance and use a corporate governance index $(\text { CORP_INDEX })^{2}$ composed of individual characteristics that are significant. We also consider sales manipulation, overproduction, and the cutting of discretionary expenses as a proxy for real activity-based earnings management and use an aggregated measure (RM_Proxy). To make sure that our findings are robust, we consider endogenous relationships among variables.

We control for firm size $(S I Z E)$, capital structure $(L E V E R A G E)^{3}$, and performance $(R O A)$. In addition, we use the largest shareholder's holding ${ }^{4}(O W N E R)$ and whether or not a firm is owner-managed (OWNER_DUMMY) to control for ownerships. Finally, we use dummy variables (IND_Dummy and YEAR_Dummy) to control for internal director's compensation (COMPEN) and for industrial and yearly effects that might exist. All these control variables follow previous studies regarding real activity-based earnings management.

In the literature on corporate governance, there is concern about endogenous relationships among variables. Managers' abnormal operational or investment decisions are both influenced by weaker corporate governance, yet also affect the structure of governance. To address this concern, we employ the following 2SLS regressions and control for endogeneity. Following a previous study (Bernard et al., 2006), we also consider a dummy variable for firms' assets (SIZE_DUMMY) in addition to firm size (SIZE), because certain applications of Korean law depend on whether firms are large ${ }^{5}$ or small.

\footnotetext{
${ }^{2}$ Corporate index is calculated by the process described in the " 3.2 measurement of variables" section

${ }^{3}$ We use total assets as a denominator because using net assets may result in negative numbers, which can distort the continuity of a firm's debt ratio.

${ }^{4}$ Data are available from the TS2000 database of the Korean listed firms' associations.

${ }^{5}$ Large firms those that have assets above 2 trillion Won have to have an internal audit committee.
} 
[Model 1-1] 2SLS regressions

$1^{\text {st }}$ Stage: $C O R P \_I N D E X_{i t}=\boldsymbol{\alpha}_{0}+\boldsymbol{\alpha}_{1} R M_{-} P_{P r O x y}+\boldsymbol{\alpha}_{2} S I Z E_{-} D U M M Y_{i t}+\boldsymbol{\alpha}_{3} S I Z E_{i t}+e_{i t}$
$\mathbf{2}^{\text {nd }}$ Stage: $R M \_P r o x y_{i t}=b_{0}+b_{1} C O R P \_I N D E X_{i t}+b_{2} S I Z E_{i t}+b_{3} L E V E R A G E_{i t}+b_{4} R O A_{i t}+b_{5} O W N E R_{i t}$
$+b_{6} C O M P E N_{i t}+b_{7} O W N E R \_D U M M Y_{i t}+b_{8 \sim 15} D I N D \_D u m m y+b_{16 \sim 17} D Y E A R \_D u m m y+e_{i t}$

where,

SIZE_DUMMY $Y_{i t}$ : Indicator variable with a value of 1 the if total assets of firm $i$ in year $t$ are equal to or above 2 trillion Won, 0 otherwise

We employ Baron and Kenny's (1986) three-stage approach to examine whether real activity-based earnings management strengthens the casual link between corporate governance and Tobin's Q, using the above findings as a basis. We review each mean value of the portfolio groups, using their corporate governance index as a basis, and examine the mediator effects using three-stage regressions ${ }^{6}$.

[Model 2]

$D E P_{i t}=\boldsymbol{\alpha}_{0}+\boldsymbol{\alpha}_{1} C O R P \_I N D E X_{i t}+\boldsymbol{\alpha}_{2} R M_{-} P_{\text {Proxy }}+\boldsymbol{\alpha}_{3} S_{\text {SII }} E_{i t}+\boldsymbol{\alpha}_{4} L E V E R A G E_{i t}+\boldsymbol{\alpha}_{5} R O A_{i t}+\boldsymbol{\alpha}_{6} O W N E R_{i t}+\boldsymbol{\alpha}_{7} C O M P E N_{i t}$ $+\boldsymbol{\alpha}_{8} O W N E R \_D U M M Y_{i t}+\boldsymbol{\alpha}_{9 \sim 16} \Sigma I N D \_D u m m y+\boldsymbol{\alpha}_{17 \sim 18} \Sigma Y E A R \_D u m m y+e_{i t}$

where,

$D E P_{i t}: R M_{-}$Proxy at the 1 st regression and Tobin's $Q$ at the2nd and 3rd regressions of firm $i$ in year $t$

Tobin's $Q_{i t}=$ A ratio comparing the market value of stock with equity book value of firm $i$ in year $t$ [(Equity market value + liability book value) $\div$ (equity book value + liability book value) $]$

\section{Measurement of Variables}

The characteristics of corporate governance that we consider are board size, activities, independence, external directors' activities, and external directors' professionalism. It is difficult to determine whether corporate governance is effective overall at controlling earnings management, because internal control factors are various and work together. In response to this difficulty, we make a corporate governance index (CORP_INDEX) composed of the significant individual characteristics ${ }^{7}$ found in the following model.

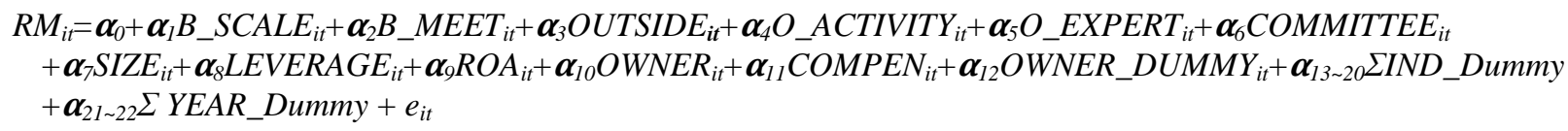

where,

$B \_S C A L E=$ Number of directors on board, which used as natural log form

$B \_M E E T=$ Number of board meetings, which used as natural log form

OUTSIDE $=$ Proportion of outside directors (\# of Outside director $\div$ \# of total directors on board)

Outside director $=$ Firm's board of directors is not current employee of the firm, regardless of an ex-employment in the firm

\footnotetext{
${ }^{6}$ [Model 2] is composed of the approaches shown below, which were used by Baron and Kenny (1986).

$1^{\text {st }}$ stage: $R M_{-}$Proxy $_{i t}=\alpha_{0}+\alpha_{l}$ CORP_INDEX $X_{i t}+$ other control variables $+e_{i t}$ $2^{\text {nd }}$ state: Tobin's $Q_{i t}=\beta_{0}+\beta_{I}$ CORP_INDEX $X_{i t}+$ other control variables $+e_{i t}$

$3^{\text {nd }}$ stage: Tobin's $Q_{i t}=\gamma_{0}+\gamma_{1}$ CORP_INDEX $X_{i t}+\gamma_{2} R M_{-}$Proxy ${ }_{i t}+$ other control variables $+e_{i t}$

If $\alpha_{1}, \beta_{1}, \gamma_{1}$, and $\gamma_{2}$ are all significant and $\gamma_{1}<\beta_{1}$ or $\gamma_{1}$ becomes insignificant, then we may conclude that RM_Proxy strengthens the causal link between CORP_INDEX and Tobin's $Q$.

${ }^{7}$ The results are consistent when we consider all components of the individual corporate governance variables used in the study
} 
$O \_A C T I V I T Y=$ Simple participation rate at board meetings by outside directors

$O \_E X P E R T=$ Proportion of outside directors as financial experts (Financial experts $=$ Professor in the field of accounting or finance, CPAs, or person who had consulting experience on finance)

COMMITTEE = Indicator variable with a value of 1 if there is audit committee within firm, 0 otherwise

We rank our sample into five groups based on each characteristic that is found to be significant in the above model; i.e., board size, activity, or independence, and assign 1 to 5 from lower to higher quintiles. Then we find their mean and get an equally weighted average score, which is the final corporate governance index.

We consider sales manipulation, overproduction, and the cutting of discretionary expenses as a proxy for real activity-based earnings management. We use a single measure (RM_Proxy) combining ${ }^{8}$ these variables to capture overall effects of abnormal real activities. Firms that manage earnings upwards are likely to have one or more of abnormal real activities. We rely on previous estimation models for normal levels of real activities and regard abnormal levels of real operations as real activity-based earnings management. The abnormal level of each measure is computed as the actual level of a variable minus its normal level. We estimate normal levels of cash flow from operations, production costs, and discretionary expenses using a procedure developed by Dechow et al. (1998), as implemented by Zang (2005) and Roychowdhury (2006), and we run cross-sectional regressions for every industry and year as follows:

$$
\begin{aligned}
& O C F_{i f} / A_{i t-1}=a_{0}\left(1 / A_{i t-1}\right)+a_{1}\left(S_{i t} / A_{i t-1}\right)+a_{2}\left(\Delta S_{i t} / A_{i t-1}\right)+e_{i t} \\
& \operatorname{COGS} S_{i t} A_{i t-1}=a_{0}\left(1 / A_{i t-1}\right)+a_{1}\left(S_{i t} / A_{i t-1}\right)+e_{i t} \\
& \Delta I N V_{i f} / A_{i t-1}=a_{0}\left(1 / A_{i t-1}\right)+a_{1}\left(\Delta S_{i t} / A_{i t-1}\right)+a_{2}\left(\Delta S_{i t-1} / A_{i t-1}\right)+e_{i t} \\
& P R O D_{i t} / A_{i t-1}=a_{0}\left(1 / A_{i t-1}\right)+a_{1}\left(S_{i t} / A_{i t-1}\right)+a_{2}\left(\Delta S_{i t} / A_{i t-1}\right)+a_{3}\left(\Delta S_{i t-1} / A_{i t-1}\right)+e_{i t} \\
& \operatorname{DISCEXP} P_{i t} / A_{i t-1}=a_{0}\left(1 / A_{i t-1}\right)+a_{1}\left(S_{i t-1} / A_{i t-1}\right)+e_{i t}
\end{aligned}
$$

where,

$O C F_{i t}$ : Cash flows from operations of firm $i$ in year $t, P R O D_{i t}$ : COGS plus $\triangle I N V$ of firm $i$ in year $t, C O G S_{i t}$ : Cost

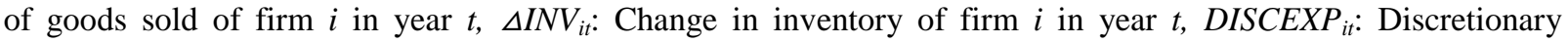
expenses of firm $i$ in year $t$ (Employee welfare + Advertising $+\mathrm{R} \& \mathrm{D}$ expense + Education and training), $A_{i t-1}$ : Total assets of firm $i$ at the beginning of year $t, S_{i t}$ : Sales of firm $i$ in year $t, \Delta S_{i t}$ : Change in sales of firm $i$ in year $t\left(S_{i t}-S_{i t-1}\right), \Delta S_{i t-1}$ : Change in sales of firm $i$ in year $t-l\left(S_{i t-1}-S_{i t-2}\right)$

We express normal cash flow from operations as a linear function of sales and changes in sales in the current period. Production costs are defined as the sum of the cost of goods sold (COGS) and the change in inventory $(\triangle I N V)$ during the year. We consider the sum of employee welfare, advertising, R\&D expense, and education and training expenses as discretionary expenses. The normal level of discretionary expenses is also expressed as a linear function of lagged sales, because modeling discretionary expense as a function of current sales creates a technical problem in that unusually low residuals can result if firms manage sales upwards to increase earnings in a certain year and estimate normal levels of discretionary expenses.

\section{Sample Selection}

We used sample listed on the Korea Stock Exchange (KSE) from 2005 to 2007. Our sample restricted to nonfinancial firms and firms that have negative capital were excluded. In order to ensure homogeneity, each firmyear observation was required to have a fiscal year ending in December and to have the data necessary to calculate the abnormal real activities used in this study. We truncated the top and bottom $1 \%$ of the distribution so that the results were not affected by outliers. Our final sample comprised 1,104 firm-year observations. Financial data were

\footnotetext{
${ }^{8}$ We multiply abnormal cash flows from operations and abnormal discretionary expense by -1 to make it easier to interpret the results. Price discount or channel stuffing has a negative effect on contemporaneous abnormal $O C F$. Excessive price discount or overproduction leads to abnormally high production costs relative to sales. Cutting discretionary expenses leads to abnormally low discretionary expenses relative to sales. Each direction implying earnings management is not the same and we make it to the same direction.
} 
obtained from the Fn-DataGuidePro database and ownership data were obtained from the TS2000. Data on corporate governance, such as board size, number of meetings, and the proportion of external directors, were all hand-collected from annual reports.

\section{EMPIRICAL RESULTS}

\section{Descriptive Statistics}

Table 1 reports the descriptive statistics on proxies for earnings management and other variables that were examined. The number of directors on the board $\left(B \_S C A L E\right)$ is about 5 6 on average. The number of meetings $\left(B \_M E E T\right)$ is about 16 times a year on average ${ }^{9}$. External directors account for $32.3 \%$ of the total number of directors $\left(\right.$ OUTSIDE) on average and their participation rate in board meetings $\left(O \_A C T I V I T Y\right)$ is $71.7 \%$. About $9.4 \%$ of the external directors are financial experts $\left(O_{-} E X P E R T\right)$ and $16.3 \%$ of the sample firms have an internal audit committee (COMMITTEE).

Table 1: Descriptive Statistics

\begin{tabular}{|c|c|c|c|c|c|}
\hline Variables & Mean & STD & $1 Q$ & Median & $3 Q$ \\
\hline RM_Proxy & -0.016 & 0.165 & -0.116 & -0.016 & 0.084 \\
\hline$A b . O C F$ & -0.002 & 0.075 & -0.051 & 0.001 & 0.044 \\
\hline Ab.PROD_cost & -0.018 & 0.109 & -0.074 & -0.011 & 0.044 \\
\hline$A b . E X P$ & 0.000 & 0.023 & -0.010 & -0.002 & 0.006 \\
\hline B_SCALE & 5.941 & 2.073 & 4.00 & 6.00 & 7.00 \\
\hline B_MEET & 16.27 & 12.90 & 8.00 & 13.00 & 20.00 \\
\hline OUTSIDE & 0.323 & 0.102 & 0.25 & 0.286 & 0.333 \\
\hline O_ACTIVITY & 0.717 & 0.288 & 0.50 & 0.813 & 1.00 \\
\hline O_EXPERT & 0.094 & 0.243 & 0.00 & 0.00 & 0.00 \\
\hline COMMITTEE & 0.163 & 0.370 & 0.00 & 0.00 & 0.00 \\
\hline CORP_INDEX & 0.599 & 0.525 & 0.20 & 0.60 & 1.00 \\
\hline SIZE & 19.33 & 1.167 & 18.44 & 19.14 & 20.07 \\
\hline LEVERAGE & 0.476 & 0.206 & 0.320 & 0.467 & 0.615 \\
\hline$R O A$ & 0.056 & 0.071 & 0.019 & 0.054 & 0.094 \\
\hline LOSS & 0.151 & 0.358 & 0.000 & 0.000 & 0.000 \\
\hline OWNER & 0.372 & 0.175 & 0.234 & 0.361 & 0.489 \\
\hline COMPEN & 0.007 & 0.009 & 0.002 & 0.004 & 0.009 \\
\hline OWNER_DUMMY & 0.281 & 0.449 & 0.000 & 0.000 & 1.000 \\
\hline Tobin's $Q$ & 0.570 & 0.222 & 0.402 & 0.564 & 0.708 \\
\hline
\end{tabular}

Notes to Table 1:

$R M \_$proxy $=$Sum of $A b . O C F, A b . P R O D \_c o s t$, and $A b . E X P$ (We multiply $A b . O C F$ and $A b . E X P$ by negative one so that the sum of the three variables will be indicative of overall real earnings management)

$A b . O C F=$ Abnormal cash flows from operations, Ab.PROD_cost $=$ Abnormal production costs, Ab.EXP $=$ Abnormal discretionary expenses (the sum of employee welfare, advertising, R\&D expense, and education and training expenses)

$B \_S C A L E=$ Number of directors on board, which used as natural $\log$ forms. $B \_M E E T=$ Number of board meetings, which used as natural $\log$ form. OUTSIDE $=$ Proportion of outside directors (\# of Outside director $\div$ \# of total directors on board), Outside director $=$ Firm's board of directors is not current employee of the firm, regardless of an ex-employment in the firm $O \_A C T I V I T Y=$ Simple participation rate at board meetings by outside directors. $O \_E X P E R T=$ Proportion of outside directors as financial experts, Financial experts $=$ Professor in the field of accounting or finance, CPAs, or person who had consulting experience on finance. COMMITTEE = Indicator variable with a value of 1 if there is audit committee within firm, 0 otherwise CORP_INDEX = Sum of $B \_S C A L E, B \_M E E T$, and $O U T S I D E$ (We multiply $B \_M E E T$ by negative one so that the sum of the three variables will be indicative of overall corporate governance)

${ }^{9}$ Simply, this is the number of board meetings and we use log specification to mitigate heteroskedasticity when we run OLS or 2SLS, including $B \_S C A L E$ and $B \_M E E T$. 
$S I Z E=$ Natural log of total assets. $L E V E R A G E=$ Debt ratio deflated by lagged assets. ROA = Return of assets (Earnings before tax/ Total Assets). LOSS = Indicator variable with a value of 1 if net income is below zero, 0 otherwise. $O W N E R=$ Large shareholder's ownership which includes holdings of a majority shareholder, his or her family, and affiliated firms which have special relations with the firm according to Article 2 of the Securities and Exchange Act. COMPEN = Board of directors' compensation which includes salary, bonus, and stock option. $O W N E R \_D U M M Y=$ Indicator variable with a value of 1 if manager is an owner, 0 otherwise. IND_Dummy = Industry dummy variables. YEAR_Dummy = Year dummy variables

Table 2 reports correlations among variables. It shows the Pearson correlation coefficients based on two tailed tests.

Table 2: Correlations

\begin{tabular}{|c|c|c|c|c|c|c|c|c|}
\hline & RM_Proxy & CORP_INDEX & SIZE & LEVERAGE & $R O A$ & OWNER & COMPEN & Tobins'Q \\
\hline RM_Proxy & & $\begin{array}{l}-0.154 \\
<.0001\end{array}$ & $\begin{array}{l}-0.133 \\
<.0001\end{array}$ & $\begin{array}{c}0.251 \\
<.0001\end{array}$ & $\begin{array}{l}-0.453 \\
<.0001\end{array}$ & $\begin{array}{c}-0.033 \\
0.278\end{array}$ & $\begin{array}{c}0.150 \\
<.0001\end{array}$ & $\begin{array}{c}0.275 \\
<.0001\end{array}$ \\
\hline CORP_INDEX & & & 0.334 & $\begin{array}{c}-0.006 \\
0.839\end{array}$ & $\begin{array}{l}0.088 \\
0.003\end{array}$ & $\begin{array}{c}-0.047 \\
0.123\end{array}$ & $\begin{array}{c}-0.110 \\
0.000\end{array}$ & $\begin{array}{l}0.001 \\
0.965 \\
\end{array}$ \\
\hline SIZE & & & & $\begin{array}{c}0.176 \\
<.0001\end{array}$ & $\begin{array}{c}0.170 \\
<.0001\end{array}$ & $\begin{array}{c}-0.062 \\
0.041 \\
\end{array}$ & $\begin{array}{l}-0.429 \\
<.0001\end{array}$ & $\begin{array}{c}-0.060 \\
0.049 \\
\end{array}$ \\
\hline LEVERAGE & & & & & $\begin{array}{l}-0.185 \\
<.0001 \\
\end{array}$ & $\begin{array}{c}-0.082 \\
0.007 \\
\end{array}$ & $\begin{array}{l}0.056 \\
0.066 \\
\end{array}$ & $\begin{array}{c}0.752 \\
<.0001 \\
\end{array}$ \\
\hline$R O A$ & & & & & & $\begin{array}{l}0.045 \\
0.135 \\
\end{array}$ & $\begin{array}{l}-0.152 \\
<.0001\end{array}$ & $\begin{array}{l}-0.426 \\
<.0001\end{array}$ \\
\hline OWNER & & & & & & & $\begin{array}{l}0.022 \\
0.467 \\
\end{array}$ & $\begin{array}{c}-0.095 \\
0.001 \\
\end{array}$ \\
\hline COMPEN & & & & & & & & $\begin{array}{l}0.100 \\
0.000\end{array}$ \\
\hline
\end{tabular}

* Pearson correlations based on two-tailed tests

Corporate governance measured by corporate index (CORP_INDEX) is associated negatively with real activity-based earnings management (RM_Proxy). Firm performance (Tobin's $Q$ ) is correlated negatively with Firm size (SIZE), while correlated positively with debt ratio (LEVERAGE).

\section{Effect on Real Activity-based Earnings Management of Corporate Governance}

Table 3 reports the results of [Model 1], which examines the associations between the corporate governance and real activity-based earnings management.

Adjusted $R^{2}$ is significant and $\boldsymbol{\alpha}_{l}$ shows a significantly negative sign $(-0.036, \mathrm{P}<0.001)$ and indicates that the overall strength of corporate governance constrains real activity-based earnings management efficiently. Regarding the results with control variables ${ }^{10}$, the debt ratio (LEVERAGE) is correlated significantly and positive with real activity-based earnings management. This suggests that firms that have greater debt are likely to be engaged in real activity-based earnings management. The association between a firm's performance $(R O A)$ and real activity-based earnings management is significant and negative, which implies that firms whose performance is poor are more likely to engage in real activity-based earnings management. Managers are likely to engage in earnings management, as measured by abnormal real activity (RM_Proxy), when the board compensation (COMPEN) is higher. Those results on control variables are consistent with correlations and previous studies.

Hermalin and Weisbach argue that the variables board structure and performance are endogenous and find that previous studies on boards, the results of which are inconsistent, often neglect this issue. We consider the issue by employing two-stage least square (2SLS) regressions and obtain results that are consistent with ours. These are reported in Table 4.

\footnotetext{
${ }^{10}$ Multicollinearity is not an issue here and the highest VIF is 1.87. 
Table 3: Regression of Earnings Management on Corporate Governance (OLS Regression)

\begin{tabular}{|c|c|c|c|}
\hline \multicolumn{4}{|c|}{ 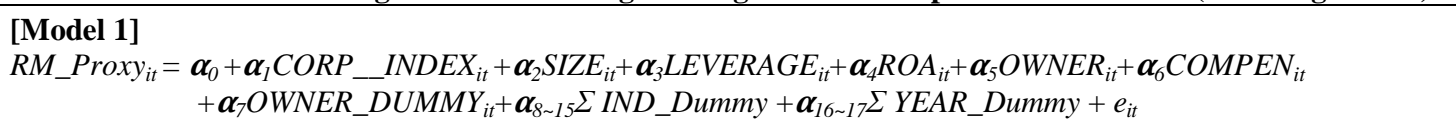 } \\
\hline \multicolumn{2}{|c|}{ Coefficients } & \multirow{2}{*}{$\begin{array}{c}\text { Exp. sign } \\
?\end{array}$} & \multirow[b]{2}{*}{$0.071(0.78)$} \\
\hline $\boldsymbol{\alpha}_{0}$ & Intercept & & \\
\hline $\boldsymbol{\alpha}_{1}$ & CORP_INDEX & - & $-0.036\left(-3.91^{* * * *}\right)$ \\
\hline$\alpha_{2}$ & SIZE & - & $-0.004(-1.02)$ \\
\hline$\alpha_{3}$ & LEVERAGE & - & $0.149\left(6.56^{* * *}\right)$ \\
\hline $\boldsymbol{\alpha}_{4}$ & $R O A$ & - & $-0.913\left(-13.6^{* * *}\right)$ \\
\hline $\boldsymbol{\alpha}_{5}$ & OWNER & - & $-0.006(-0.24)$ \\
\hline $\boldsymbol{\alpha}_{6}$ & COMPEN & - & $1.003\left(1.87^{*}\right)$ \\
\hline $\boldsymbol{\alpha}_{7}$ & OWNER_DUMMY & $+/-$ & $-0.0003(-0.03)$ \\
\hline $\boldsymbol{\alpha}_{8 \sim 15}$ & IND_Dummy & $+/-$ & Inc. \\
\hline $\boldsymbol{\alpha}_{16 \sim 17}$ & YEAR_Dummy & $+/-$ & Inc. \\
\hline \multicolumn{3}{|c|}{$F$} & $48.8^{* * *}$ \\
\hline \multicolumn{3}{|c|}{$\operatorname{Adj.} R^{2}$} & 24.0 \\
\hline \multicolumn{3}{|c|}{$N$} & 1,104 \\
\hline
\end{tabular}

Notes to Table 3:

$R M \_$proxy $_{i t}$ : The sum of $A b . O C F, A b . P R O D \_c o s t$, and $A b . E X P$ of firm $i$ in year $t$ (we multiply Ab.OCF and Ab.EXP by -1 so that the sum of the three variables will be indicative of overall real earnings management)

CORP_INDEX $X_{i t}$ : The sum of $B \_S C A L E, B \_M E E T$, and $O U T S I D E$ of firm $i$ in year $t$ (we multiply $B \_M E E T$ by -1 so that the sum of the three variables will be indicative of overall corporate governance)

Table 4: Regression of Earnings Management on Corporate Governance (2SLS)

\begin{tabular}{|c|c|c|c|}
\hline \multicolumn{4}{|c|}{ 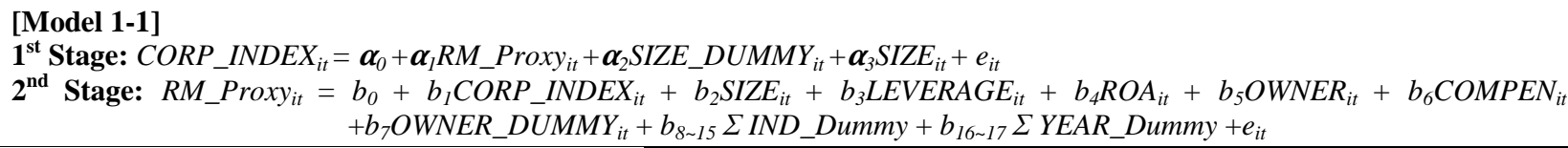 } \\
\hline \multicolumn{2}{|c|}{ Coefficients } & Exp. sign & \\
\hline$b_{0}$ & Intercept & $?$ & $-0.277\left(-1.78^{*}\right)$ \\
\hline$b_{1}$ & CORP_INDEX & $+/-$ & $-0.18\left(-3.57^{* * *}\right)$ \\
\hline$b_{2}$ & SIZE & - & $0.017\left(1.81^{*}\right)$ \\
\hline$b_{3}$ & LEVERAGE & - & $0.142\left(6.16^{* * *}\right)$ \\
\hline$b_{4}$ & $R O A$ & - & $-0.83\left(-11.75^{* * *}\right)$ \\
\hline$b_{5}$ & OWNER & - & $-0.004(-0.20)$ \\
\hline$b_{6}$ & COMPEN & - & $0.907\left(1.74^{*}\right)$ \\
\hline$b_{7}$ & OWNER_DUMMY & $+/-$ & $0.005(0.59)$ \\
\hline$b_{8 \sim 15}$ & IND_Dummy & $+/-$ & Inc. \\
\hline$b_{16 \sim 17}$ & YEAR_Dummy & $+/-$ & Inc. \\
\hline \multicolumn{3}{|c|}{$F$} & $39.3^{* * *}$ \\
\hline \multicolumn{3}{|c|}{$\operatorname{Adj.} R^{2}$} & 20.1 \\
\hline \multicolumn{3}{|c|}{$N$} & 1,104 \\
\hline
\end{tabular}

Notes to Table 4:

CORP_GOV $V_{i t}$ : Individual characteristic of corporate governance or aggregate index; $B_{-} S C A L E, \quad B \_M E E T$, OUTSIDE, $O \_A C T I V I T Y, O \_E X P E R T$ and $C O R P \_I N D E X$

CORP_INDEX $X_{i t}$ : The sum of $B \_S C A L E, B \_M E E T$, and $O U T S I D E$ of firm $i$ in year $t$ (we multiply $B \_M E E T$ by -1 so that the sum of the three variables will be indicative of overall corporate governance)

$S I Z E \_D U M M Y_{i t}$ : Indicator variable with a value of 1 if the total assets of firm $i$ in year $t$ are equal to or above 2 trillion Won, 0 otherwise 
In the first stage, we run real activity-based earnings management (RM_Proxy) and corporate governance aggregately (CORP_INDEX), where we control for firm size (SIZE) and size dummy (SIZE_DUMMY $)^{11}$. We obtain a result in the second-stage regression that is consistent with our main results, even though each coefficient of corporate governance $\left(C O R P_{-} I N D E X\right), b_{1}$, is larger than the OLS coefficients in Table 3 and significant.

\section{Real Activity-based Earnings Management as a Mediator}

Finally, we examine the mediator role of real activity-based earnings management using the approach proposed by Baron and Kenny (1986) and suggest that it strengthens the causal link between corporate governance, as measured by the corporate governance index, and firm performance, as measured by Tobin's Q. Table 5 shows the results. Panel A reports each mean value of real activity-based earnings management and Tobin's Q, using corporate governance index portfolios as a basis. The lowest corporate governance group (Q1) has the highest mean of real activity-based earnings management (0.011) and the lowest mean of Tobin's Q (0.527) among the groups. These results are consistent with the results of correlations and the OLS results, which indicate that corporate governance is associated negatively with real activity-based earnings management and associated positively with firm performance. The relationship between real activity-based earnings management and performance is negative.

Table 5: Mediator Effects of Real activity-based Earnings Management

Panel A: Corporate Governance Index Portfolios

\begin{tabular}{|c|c|c|c|}
\hline Portfolio & $\begin{array}{c}\text { Corporate Governance } \\
\text { Index(CORP_INDEX) }\end{array}$ & $\begin{array}{c}\text { Real Activity-based Earnings } \\
\text { Management(RM_Proxy) }\end{array}$ & $\begin{array}{c}\text { Performance } \\
\text { (Tobin's Q) }\end{array}$ \\
\hline Q1(low) & -0.133 & 0.011 & 0.527 \\
\hline Q2 & 0.285 & 0.005 & 0.530 \\
\hline Q3 & 0.590 & -0.011 & 0.544 \\
\hline Q4 & 0.913 & -0.035 & 0.572 \\
\hline Q5(High) & 1.344 & -0.060 & 0.587 \\
\hline
\end{tabular}

Panel B: Baron and Kenny's Three-stage Approach

[Model 2]

$D E P_{i t}=\boldsymbol{\alpha}_{0}+\boldsymbol{\alpha}_{1} C O R P_{-} I N D E X_{i t}+\boldsymbol{\alpha}_{2} R M_{-}$Proxy $_{i t}+\boldsymbol{\alpha}_{3} S_{\text {SIZ }}+\boldsymbol{\alpha}_{4} L_{\text {LVVERAGE }}+\boldsymbol{\alpha}_{5} R O A_{i t}+\boldsymbol{\alpha}_{6} O W N E R_{i t}+\boldsymbol{\alpha}_{7}$ COMPEN $_{i t}$ $+\boldsymbol{\alpha}_{8} O W N E R \_D U M M Y_{i t}+\boldsymbol{\alpha}_{9 \sim 16} \sum I N D \_D u m m y+\boldsymbol{\alpha}_{17 \sim 18} \sum Y E A R \_D u m m y+e_{i t}$

\begin{tabular}{|c|c|c|c|c|c|}
\hline \multirow{2}{*}{\multicolumn{2}{|c|}{${ }_{\text {Coefficients }}$ Dependents }} & \multirow{2}{*}{$\begin{array}{c}\text { Exp. } \\
\text { sign }\end{array}$} & 1st stage regression & 2nd stage regression & 3rd stage regression \\
\hline & & & RM_Proxy & Tobin's $Q$ & Tobin's $Q$ \\
\hline $\boldsymbol{\alpha}_{0}$ & Intercept & $?$ & $0.071(0.78)$ & $1.010\left(12.8^{* * *}\right)$ & $1.015\left(12.91^{* * *}\right)$ \\
\hline$\alpha_{1}$ & CORP_INDEX & - & $-0.036\left(-3.91^{\text {***** }}\right)$ & $0.028\left(3.57^{* * *}\right)$ & $0.026\left(3.22^{* * * *}\right)$ \\
\hline$\alpha_{2}$ & RM_Proxy & - & - & - & $-0.075\left(-2.83^{* * * *}\right)$ \\
\hline$\alpha_{3}$ & SIZE & - & $-0.004(-1.02)$ & $-0.038\left(-9.45^{* * *}\right)$ & $-0.039\left(-9.57^{* * * *}\right)$ \\
\hline$\alpha_{4}$ & LEVERAGE & - & $0.149\left(6.56^{* * *}\right)$ & $0.804\left(40.4^{* * *}\right)$ & $0.815\left(40.3^{* * * *}\right)$ \\
\hline $\boldsymbol{\alpha}_{5}$ & $R O A$ & - & $-0.913\left(-13.6^{* * *}\right)$ & $-0.838\left(-14.3^{* * *}\right)$ & $-0.908\left(-14.3^{* * * *}\right)$ \\
\hline$\alpha_{6}$ & OWNER & - & $-0.006(-0.24)$ & $-0.052\left(-2.36^{* *}\right)$ & $-0.052\left(-2.39^{* *}\right)$ \\
\hline$\alpha_{7}$ & COMPEN & $+/-$ & $1.003\left(1.87^{*}\right)$ & $-1.284\left(-2.76^{* * * *}\right)$ & $-1.208\left(-2.60^{* * * *}\right)$ \\
\hline $\boldsymbol{\alpha}_{8}$ & OWNER_DUMMY & & $-0.0003(-0.03)$ & $-0.031\left(-3.64^{* * *}\right)$ & $-0.031\left(-3.66^{* * *}\right)$ \\
\hline $\boldsymbol{\alpha}_{9 \sim 16}$ & IND_Dummy & $+/-$ & Inc. & Inc. & Inc. \\
\hline $\boldsymbol{\alpha}_{17 \sim 18}$ & YEAR_Dummy & $+/-$ & Inc. & Inc. & Inc. \\
\hline & $F$ & & $48.8^{* * * *}$ & $323.8^{* * *}$ & $286.2^{* * * *}$ \\
\hline & Adj. $R^{2}$ & & 24.0 & 68.1 & 68.3 \\
\hline & $N$ & & 1,104 & 1,104 & 1,104 \\
\hline
\end{tabular}

Notes to Table 5:

Baron and Kenny's (1986) three-stage approach to examining mediating effects

$D E P_{i t}: R M_{-}$Proxy at 1 st regression and Tobin's $Q$ at the 2 nd and 3 rd regressions of firm $i$ in year $t$

${ }^{11}$ An asset dummy that indicates large firms is considered in this study, following Black et al. (2006). Multicollinearity is insignificant. 
The results presented in Panel $B$ show that real activity-based earnings management strengthens the casual link between corporate governance and firm performance. If the significance of $\boldsymbol{\alpha}_{l}$ of the third-stage regression disappears or is lower than $\boldsymbol{\alpha}_{l}$ of the second-stage regression ${ }^{12}$, we may infer that real activity-based earnings management strengthens the association between corporate governance and Tobin's Q. The results accord with our expectations (t value, $3.22<3.57$, where all $\boldsymbol{\alpha}_{1}$ and $\boldsymbol{\alpha}_{2}$ are significant). The results for other control variables are consistent with our main results. Thus, we confirm that managers' abnormal real activity strengthens the casual link between corporate governance and performance. In a situation in which an inefficient structure of governance may cause firms to underperform, managers' management of earnings via abnormal operations/investment could make it worse.

\section{CONCLUSION}

Previous studies reported that corporate governance effectively controls accrual-based earnings management. However, the managers' preference on earnings management tool has been changed from accounting choices to arbitrary business decisions after the passage of the SOX Act in 2002. There are also renewed interests in corporate governance since 2002 as a result of big accounting scandals, such as bankruptcy of Enron or WorldCom, so that a financial reporting gets public confidence again. If corporate governance effectively operated within a firm, then it constrained managers' both accruals and real activity-based earnings management, which eventually influences shareholders' wealth. This study examined whether earnings management is controlled by corporate governance in the context of managers' abnormal real activity and whether it strengthens the casual link between corporate governance and firm performance.

We used a corporate governance index as corporate governance and a combined proxy for real activitybased earnings management in order to catch overall effects. Our results indicate that managers are less likely to be engaged in real activity-based earnings management when corporate governance index is high, and this is consistent when we consider endogenous problems among variables. Finally, using as a basis our findings and those of previous studies such that real activity-based earnings management has a negative effect on firms' performance, we suggest that real activity-based earnings management mediates between corporate governance and firm performance (as measured by Tobin's Q), thereby strengthening the causal link between them.

This is the first empirical evidence that firms' real operational or investment decisions could be influenced by well-established governance structure. Eventually, it may influence firms' performance and managers' real activity-based earnings management could amplify this link between corporate governance and performance. It also provides great implications to practitioners or policy makers of jurisdictions in which ownership is highly concentrated, such as Korea. However, the results are subject to any biases inherent in the estimation model.

\section{ACKNOWLEDGEMENT}

This work is supported by the Kumoh National Institute of Technology Research Grant of 2010. We appreciate the valuable comments and suggestions from two anonymous reviewers.

\section{AUTHOR INFORMATION}

Sun-A Kang got M.A and Ph.D. in Business administration at Sogang University in Korea. She worked as an AICPA at PWC Samil accounting firm and as a senior researcher at ETRI (Electronics and Telecommunications Research Institute). Currently she is an associate professor of Kumoh National University in the field of Management. Her research interests are financial accounting, especially earnings management, corporate governance, and regulatory cost accounting.

Yong-Shik Kim got M.A and Ph.D. in Business administration at Sogang University in Korea. He worked as a KICPA at Deloitte Anjin accounting firm for 5 years and at finance deportment of Seoul City Hall for 2 years. Now he is an associate professor of Hansung University from 2009. He has interested in financial accounting, IFRS, and corporate governance.

\footnotetext{
${ }^{12}$ Details are explained in footnote \#9.
} 


\section{REFERENCES}

1. Ahmed, A. and S. Duellman. 2007. Evidence on the Role of Accounting Conservatism in Corporate Governance. AAA 2008 Financial Accounting and Reporting Section (FARS) Paper.

2. Baek. J. S., J. K. Kang, and K. S. Park. 2004. Corporate governance and firm value: Evidence from the Korean financial crisis. Journal of Financial Economics 71:265-313

3. Baron, R. M. and D. A. Kenny. 1986. The Moderator-Mediator variable distinction in Social Psychological research: Conceptual, strategic, and statistical considerations. Journal of Personality and Social Psychology. 51. 1173-1182.

4. Bartov, E. 1993. The Timing of Asset Sales and Earnings Manipulation. The Accounting Review 68. 840855.

5. Baysinger, B. and H. N. Butler. 1985. Corporate Governance and the Board of Directors: Performance and Finance Effects of Changes in Board Composition. Journal of Law, Economics, and Organization 1(1). 101-124.

6. Beasley, M. S. 1996. An empirical analysis of the relation between the board of director composition and financial statement fraud. The Accounting Review 71.43-465.

$7 . \quad$ J. J. V. Carcello, D. R. Hermanson, and P. D. Lapides. 2000. Fraudulent financial reporting: Consideration of industry traits and corporate governance mechanisms. Accounting Horizons 14. 441-454.

8. _ and S. Salterio. 2001. The relationship between board characteristics and voluntary improvements in the capability of audit committees to monitor. Contemporary Accounting Research 18. 539-570.

9. Bernard S. Black, H. S. Jang, and W. C. Kim. 2006. Does corporate governance predict firms' market value? Evidence from Korea. Journal of Law, Economics, and Organization 22(2):366-413.

10. Choi, W. S. 2004. The Trade-Off Relationship of Tax Costs and Nontax Costs on Income from Asset Sales. Korean Accounting Review 29. 253-291.

11. Cohen, D., A. A. Dey, and T. Lys. 2008. Real and Accrual-based Earnings Management in the Pre- and Post-Sarbanes Oxley Periods. Accounting Review 83(3). 757-787.

12. Dalton, D. R, J. L. Johnson, and A. E. Ellstrand. 1999. Number of Directors and Financial Performance: A Meta-Analysis. Academy of Management Journal 42(6). 674-686.

13. Dechow, P., S. Kothari, and R. Watts. 1998. The relation between earnings and cash flows. Journal of Accounting and Economics 25. 133-168.

14. Graham, J. R., C. R. Harvey, and S. Rajgopal. 2005. The Economic Implications of Corporate Financial Reporting. Journal of Accounting and Economics 40. 3-73.

15. Gunny, K. 2005. What are the consequences of real earnings management?. Working paper. University of Colorado.

16. Hermalin, B., Weisbach, M. 1991. The effects of board composition and direct incentives on firm performance. Financial Management 20. 101-112.

17. Herrmann, D., T. Inoue and W. Thomas. 2003. The sale of assets to manage earnings in Japan. Journal of Accounting Research 41(1). 89-108.

18. Kang, S. A. and S. B. Chun. 2010. Characteristics of Firms Engaged in Real Activity-based Earnings Management: Evidence from Korea. Korean Accounting Review 35(2). 35-70.

19. Kang, S. A. and S. B. Chun. 2010. Consequences of Real Activity-based Earnings Management: Evidence of Seasoned Equity Offering Firms in Korea. Korean Management Review 29(3). 595-632.

20. Kim, B. H. 2006. The Influence of the Board Composition on Earnings Management in Korean Firms: Looking at Cases of Upwards and Downwards Management. Korean Accounting Review 31(1). 1-32.

21. Kim, C. S. 2006. Outside Directors and Firm Value in Korea. The Korean Journal of Finance 19(2). 105153.

22. Kim, J. H., J. M. Goh, and Y. S. Koh. 2008. Real Earnings Management to avoid Loss and Smooth Income, Expectations. Korean Accounting Journal (17). 31-63.

23. Kim, J. O. and G. S. Bae. 2007. Corporate Governance and Accounting Conservatism: Evidence from Board and Audit Committee Characteristics. Korean Accounting Review 32(2). 89-115.

24. Klien, A. 2002. Economic determinants of audit committee. The Accounting Review 77(2). 30-56.

25. Roychowdhury, S. 2006. Earnings Management through Real Activities Manipulation. Journal of Accounting and Economics 42. 335-370. 
26. Uzun, H., S. H. Szewczyk, and R. Varma. 2004. Board Composition and Corporate Fraud. Financial Analyst Journal 60(3). 33-43.

27. Xie. B., W. No. Davidson III, and P. J. Dadalt. 2003. Earning Management and Corporate Governance: The Role of the Board and the Audit Committee. Journal of Corporate Finance 9. 295-316.

28. Yermack, D. 1996. Higher market valuation of companies with a small board of directors. Journal of Financial Economics 40. 185-212.

29. Zang, A. Y. 2005. Evidence on the Tradeoff between Real Manipulation and Accruals Manipulation. Working paper. Duke University.

\section{NOTES}

